\title{
Szkoły Promujące Zdrowie. Przesłanki i założenia teoretyczne dla działalności praktycznej
}

KEYWORDS

school promotes a health, health promotion, health education, health, prevention, lifestyle

\begin{abstract}
Herman Tomasz, Szkoły Promujące Zdrowie. Przesłanki i założenia teoretyczne dla działalności praktycznej [Health Promoting Schools. Theoretical Indications and Assumption for Practical Activities]. Kultura Społeczeństwo - Edukacja nr 2(6) 2014, Poznań 2014, pp. 119-134, Adam Mickiewicz University Press. ISBN 978-83-232-2869-1. ISSN 2300-0422

In this article author will approximate the concept, history and organization of the health promoting school. Successively the key concepts for this model: health, health behaviors, lifestyle health promotion, health education and prevention will be discussed. The author shows how much importance they have for the practical dimension of this project's rationale and theoretical assumptions.
\end{abstract}

Podjęcie zasygnalizowanej w tytule problematyki wynika z chęci przybliżenia koncepcji szkoły promującej zdrowie i wskazania, jak istotne znacznie dla praktycznego wymiaru tego projektu mają przesłanki i założenia teoretyczne.

\section{Kluczowe pojęcia dla koncepcji szkół promujących zdrowie}

Zanim zostaną zaprezentowane założenia teoretyczne koncepcji szkoły promującej zdrowie oraz ich wpływ na funkcjonowanie placówki, należy w pierwszej kolejności przybliżyć i omówić istotne dla niej pojęcia. Pierwsze z nich to zdrowie oraz czynniki je warunkujące. Trudno jednoznacznie zdefiniować pojęcie zdrowia. Wynika to między innymi $\mathrm{z}$ istnienia szerokiego spektrum koncepcji pojmowania zdrowia i choroby (por. Kasperek, 1999), a także, i chyba przede wszystkim, z wysoce subiektywnego pojmowania tegoż zagadnienia przez każdą jednostkę. Dla 
każdej osoby zdrowie można oznaczać zupełnie coś innego. Poniżej zostaną pokrótce omówione wybrane definicje.

W modelu biomedycznym zdrowie rozumiane jest jako brak choroby, dysfunkcji oraz zakłóceń w przebiegu procesów biologicznych w komórkach organizmu (Kasperek, 1999: 14). W opozycji do powyższej pozostaje definicja zaproponowana przez Światową Organizację Zdrowia (WHO), która przez zdrowie rozumie „nie tylko brak choroby lub niepełnosprawności, lecz stan dobrego samopoczucia fizycznego i społecznego" (Woynarowska, Sokołowska, 2000: 13). Ciekawą definicję, pozostającą w obrębie modelu socjomedycznego, proponuje Talcott Parsons, dla którego zdrowie to stan, w którym jednostka przejawia umiejętności efektywnego pełnienia ról społecznych oraz wykonywania zadań wyznaczonych jej w procesie socjalizacji (Parsons, 1969: 68). Warto również wspomnieć o modelu salutogenezy Aarona Antonovsky'ego, gdyż jest on obecnie wykorzystywany w działaniach promocji zdrowia. Zdrowie i choroba w tej perspektywie są krańcami jednego kontinuum. Jednostka zajmuje pewną pozycje pomiędzy biegunami „absolutnego zdrowia” i „całkowitej choroby”. Jeśli buduje własne zasoby i potrafi skutecznie radzić sobie ze stresem, to przesuwa się w stronę bieguna zdrowia (Woynarowska, 2007: 32-33).

Obecnie istnieje trend pojmowania zdrowia w ujęciu holistycznym, które traktuje jednostkę jako „całość” i „część całości”. W tej koncepcji wyróżnia się cztery aspekty zdrowia, które są ze sobą wzajemnie powiązane.

- Zdrowie fizyczne - związane jest z prawidłowym funkcjonowaniem organizmu, wszystkich jego układów i narządów.

- Zdrowie psychiczne - w obrębie którego wyróżnia się zdrowie umysłowe, czyli zdolność do klarownego i logicznego myślenia, oraz zdrowie emocjonalne, tj. zdolność do rozpoznawania i wyrażania uczuć w sposób aprobowany społecznie, a także umiejętność radzenia sobie ze stresem, napięciami, lękiem i depresją.

- Zdrowie społeczne - to przede wszystkim umiejętność nawiązywania oraz podtrzymywania prawidłowych relacji interpersonalnych oraz pełnienia ról społecznych.

- Zdrowie duchowe - jest trudne do zdefiniowania. Dla niektórych osób związane jest $\mathrm{z}$ wierzeniami i praktykami religijnymi, a dla innych wiąże się z życiowymi zasadami oraz sposobami utrzymywani wewnętrznego spokoju (Woynarowska, 2007: 27-34).

Zdrowie jest uwarunkowane wieloma czynnikami. Dzieli się je na cztery zasadnicze grupy: styl życia (odpowiada w ok. 50\% za zdrowie), środowisko fizyczne 
i społeczne życia (ok. 20\%), czynniki genetyczne (ok. 20\%), służba zdrowia (ok. $10 \%)$. Wskazuje się, że największy wpływ na zdrowie ludzi mają czynniki społeczno-ekonomiczne (dochód, status społeczny, poziom wykształcenia, sytuacja mieszkaniowa) (Woynarowska, Sokołowska, 2000: 14).

Drugie pojęcie, także istotne $\mathrm{w}$ podejmowanej problematyce, to zachowania zdrowotne i styl życia. Zachowania zdrowotne to wszelkie działania lub ich zaniechanie, które w sposób pośredni lub bezpośredni wpływają na zdrowie człowieka. W literaturze przedmiotu wyróżnia się dwie podstawowe kategorie: (1) zachowania prozdrowotne - sprzyjają zdrowiu, niosą ze sobą pozytywne działania, przyczyniają się do zachowywania i utrzymywania zdrowia, osiągania dobrej kondycji fizycznej i psychicznej, przeciwdziałają zaburzeniom zdrowia oraz chorobom, a także ułatwiają powrót do zdrowia w przypadku jego utraty; do zachowań prozdrowotnych zaliczamy m.in. podejmowanie aktywności fizycznej, unikanie używek, racjonalne odżywianie, adekwatne relacje interpersonalne, utrzymywanie higieny osobistej oraz otoczenia itp.; (2) zachowania antyzdrowotne - zachowania niesprzyjające zdrowiu, niosące negatywne działania, przyczyniają się do powstawania zaburzeń zdrowia, obniżenia samopoczucia, a także utrudniają powrót do zdrowia w sytuacji jego utraty; do zachowań antyzdrowotnych zaliczamy m.in. nadużywanie alkoholu, palenie tytoniu, nadmierne i nieuzasadnione zażywanie lekarstw itp. (Kasperek, 1999: 30).

Styl życia jest pojęciem szerszym. Według Światowej Organizacji Zdrowia termin ten oznacza „sposób życia oparty na wzajemnym związku pomiędzy warunkami życia w szerokim sensie a indywidualnymi wzorami zachowań zdeterminowanymi przez czynniki społeczno-kulturowe i cechy indywidualne" (Kasperek, 1999: 38). Jest to świadome zachowanie, które sprzyja poprawie, zachowaniu i ochronie zdrowia.

Trzecim istotnym zagadnieniem dla omawianej koncepcji jest promocja zdrowia. Jest to pojęcie wielowymiarowe i złożone. Poniżej zaprezentowano wybrane przykłady definicji, które wzajemnie się uzupełniają, akcentując różne aspekty tegoż problemu. Promocję zdrowia można zatem rozumieć jako:

(1) „Proces umożliwiający ludziom kontrolę nad własnym zdrowiem i jego poprawę” (Majewicz, 2011: 123).

(2) „Jednolity proces działań zmierzających do poprawy i utrzymania ludzkiego zdrowia, który składa się z trzech ściśle związanych ze sobą elementów, tj. edukacji zdrowotnej, zapobieganiu chorobom i ochrony zdrowia, a wyrażany jest przede wszystkim poprzez lokalną politykę zdrowotną” (Karski, 2007: 19). 
(3) „Połączenie edukacji zdrowotnej i prozdrowotnej polityki publicznej” (Woynarowska, 2007: 131).

(4) „Połączenie działań edukacyjnych oraz różnego rodzaju wsparcia - środowiskowego, społecznego, ekonomicznego, prawnego i taktycznego - sprzyjających zdrowiu" (Woynarowska, 2007: 131).

Pierwsza z wymienionych definicji - przyjęta na Międzynarodowej Konferencji Promocji Zdrowia w Ottawie w Kanadzie w roku 1986 - jest najczęściej cytowana $\mathrm{w}$ literaturze przedmiotu. Wynika to $\mathrm{z}$ faktu, iż wpisuje się ona $\mathrm{w}$ konwencję socjoekologiczną, czego rezultatem jest pojmowanie promocji zdrowia jako działalności motywującej oraz utrzymującej procesy społeczne, które pozytywnie wpływają na zdrowie, rozumiane jako wartość (Majewicz, 2011: 123).

Odwołując się do definicji promocji zdrowia zawartej w Karcie Ottawskiej, można stwierdzić, iż jej głównym celem jest kontrolowanie i utrzymywanie własnego zdrowia przez jednostki. Cel ten można osiągnąć poprzez spełnienie uwarunkowań dobrego samopoczucia: (1) możliwości pełnego korzystania z praw i swobód obywateli, (2) uzyskania odpowiedniego wykształcenia, (3) możliwości zatrudnienia, (4) utrzymywania kondycji psychofizycznej stosownej do wieku i płci, (5) odpowiednich warunków pracy, (6) dobrych warunków mieszkalnych, (7) możliwości komunikacji i łączności, (8) możliwości rozrywki, wypoczynku i regenerowania sił, (9) możliwości oszczędzania (10) poczucia bezpieczeństwa, (11) odpowiedniego odżywiania (Karski, 2007: 39).

Strategia działania w ramach promocji zdrowia obejmuje pięć wzajemnie powiązanych ze sobą obszarów działań:

(1) Budowanie prozdrowotnej polityki publicznej - decyzje polityczne rządu wpływają na większość czynników warunkujących zdrowie. Mechanizmy prawne, ekonomiczne i administracyjne winne są gwarantować równość w dostępie do istotnych zasobów dla zdrowia, takich jak: żywność, ubranie, mieszkanie, satysfakcjonująca praca itp. W polityce publicznej zdrowie winno być traktowane jako inwestycja społeczna. Ponadto, rząd powinien stwarzać odpowiednie warunki do wdrażania koncepcji promocji zdrowia.

(2) Tworzenie środowisk wspierających zdrowie we wszystkich miejscach, $\mathrm{w}$ których funkcjonują ludzie, a więc w domu, miejscu pracy, nauki, środowisku lokalnym.

(3) Wzmacnianie działań społecznych - stwarzanie członkom danego środowiska możliwości uczestniczenia w podejmowaniu decyzji i realizacji oraz ewaluacji działań na rzecz zdrowia. Ujmując to innymi słowy - uczenie społeczeństwa odpowiedzialności za swoje zdrowie. 
(4) Rozwijanie umiejętności indywidualnych - poprzez edukację do zdrowia, która winna obejmować umiejętności życiowe. Ukształtowanie ich pozwoli jednostkom na dokonywanie wyborów sprzyjających zdrowiu i rozwojowi. Edukacja do zdrowia powinna być realizowana zarówno w domu, szkole, miejscu pracy, jak i w społeczności lokalnej.

(5) Reorientacja służby zdrowia - zakłada uwzględnienie, obok funkcji diagnostycznych oraz leczniczych, działań ukierunkowanych na pomoc jednostkom i całym społecznościom w identyfikowaniu i zaspakajaniu potrzeb związanych z zdrowiem (Woynarowska, 2007: 132-133).

W realizacji założeń promocji zdrowia zastosowano innowacyjne podejścia i strategie. Należą do nich:

- Podejście siedliskowe - „siedlisko jest to miejsce, w którym ludzie korzystają i kształtują środowisko oraz gdzie tworzą lub rozwiązują problemy związane ze zdrowiem" (Woynarowska, 2007: 132). W teorii promocji zdrowia siedlisko jest utożsamiane $\mathrm{z}$ systemem społecznym. Obiektem interwencji w tym ujęciu nie jest jednostka, a całe systemy społeczne. Podejście to daje możliwość utożsamienia się z własnym siedliskiem i podjęcia wspólnego wysiłku w rozwiązywaniu problemu. Stanowisko to jest podstawą dwóch grup projektów: (1) projekty społeczności, np. zdrowe miasto, szkoła promująca zdrowie, program zdrowia w zakładzie pracy; (2) systemy opieki zdrowotnej promującej zdrowie, np. szpitale promujące zdrowie.

- Podejście „od ludzi do problemu” - stanowisko to wskazuje na dwa podstawowe kierunki działań w obrębie promocji zdrowia: środowiska i stylu życia. Społeczność szkolna sama identyfikuje swoje potrzeby zdrowotne oraz trudności w tym zakresie, określa problemy priorytetowe i podejmuje działania, aby je rozwiązać, korzystając z pomocy z zewnątrz.

- Podejście uczestniczące - w tym ujęciu instytucje i placówki nadrzędne podejmują próbę odpowiedzenia na pytanie: co ludzie mogą sami zrobić dla swojego zdrowia i w czym możemy im pomóc? Innymi słowy, angażują jednostki w proces dbania o zdrowie indywidualne i społeczne.

- Strategia dokonywania zmian - efektywny proces zmian uwzględnia trzy zasadnicze etapy:

(1) inicjację - zaaprobowanie decyzji o dokonaniu zmiany oraz budowanie akceptacji i porozumienia dla jej wdrożenia;

(2) wdrażanie - realizacja innowacji poprzez wprowadzenie w życie opracowanego planu działania; 
(3) instytucjonalizację - wprowadzona innowacja z biegiem czasu przestaje być postrzegana jako coś nowego, a nabiera charakteru rutynowej działalności.

- Demokratyzacja życia w szkole - jest jednym z podstawowych postulatów Europejskiej Sieci Szkół Promujących Zdrowie. Dokonuje się ono przede wszystkim poprzez:

(1) rozwój samorządności - uczniowie maja prawo oraz możliwość współdecydowania o swojej klasie, szkole, sobie i swoim zdrowiu;

(2) demokratyzację komunikowania się ludzi.

- Budowanie dialogu i współpracy poprzez wzajemne słuchanie się i wymianę informacji, a także poprzez empatię oraz szacunek do innych (Woynarowska, Sokołowska, 2006: 131).

Następne pojęcie to edukacja zdrowotna. Powyżej omówione strategie działania i podejścia nie wynikają tylko $\mathrm{z}$ koncepcji promocji zdrowia. Zagadnienie to jest silnie powiązane z pojęciem edukacji zdrowotnej. Edukację zdrowotną definiuje się jako: „całożyciowy proces uczenia się ludzi, jak żyć, aby: (1) zachować i doskonalić zdrowie własne oraz innych, (2) w przypadku wystąpienia choroby lub niepełnosprawności aktywnie uczestniczyć w jej leczeniu, radzić sobie i zmniejszać jej negatywne skutki” (Woynarowska, 2007: 103).

Wyróżnia się trzy modele edukacji zdrowotnej:

(1) Model zorientowany na chorobę - głównym celem w tym ujęciu jest zapobieganie konkretnym chorobom.

(2) Model zorientowany na czynniki ryzyka - tutaj podejmowane działania polegają na eliminowaniu czynników ryzyka w celu zapobiegania nie konkretnej chorobie, a całej ich palecie.

(3) Model zorientowany na zdrowie - podkreśla pozytywny aspekt/wymiar zdrowia, a nie tylko czynniki ryzyka. Głównym celem w tym modelu jest wzmacnianie potencjału zdrowia $\mathrm{w}$ trzech wymiarach funkcjonowania jednostki: społecznym, fizycznym oraz psychicznym. Charakteryzuje się holistycznym podejściem do zdrowia (Majewicz, 2011: 137).

Edukacja zdrowotna i promocja zdrowia pozostają ze sobą w ścisłym związku. Ma on charakter hierarchiczny. Promocja zdrowia zajmuje pozycję nadrzędną względem edukacji zdrowotnej. Edukacja zdrowotna jest niejako wpisana w promocję zdrowia. Nie ma bowiem możliwości podejmowania działania na rzecz zdrowia bez umiejętności oraz kompetencji nabywanych w wyniku edukacji zdrowotnej (Majewicz, 2011: 121). Można powiedzieć, iż edukacja zdrowotna odnosi się do procesu, w którym jednostki uczą się dbać o zdrowie własne, jak i społecz- 
ności, w której przyszło im funkcjonować (Syrek, Borzucka-Sitkiewicz, 2009: 206). Natomiast promocja zdrowia odnosi się do działań ukierunkowanych na poszczególne systemy społeczne (Woynarowska, 2000: 423).

Promocja zdrowia jest często mylnie utożsamiana z kolejnym pojęciem, profilaktyką. Poniżej zaprezentowana jest tabela ukazująca różnice między działaniami podejmowanymi w profilaktyce i w promocji zdrowia.

Tabela 1. Różnice między działaniami w profilaktyce chorób i promocji zdrowia (źródło: Woynarowska, 2007: 13)

\begin{tabular}{|c|c|c|}
\hline Cecha & \multicolumn{2}{|c|}{ Działania w: } \\
\hline & profilaktyce chorób & promocji zdrowia \\
\hline Punkt wyjścia & choroba & zdrowie \\
\hline Cel & $\begin{array}{l}\text { uniknięcie choroby - zachowanie } \\
\text { obecnego stanu - status quo, } \\
\text { akcent na wybrane grupy populacji }\end{array}$ & zwiększenie potencjału zdrowia \\
\hline Adresaci & $\begin{array}{l}\text { zwłaszcza osoby o większym } \\
\text { ryzyku choroby }\end{array}$ & $\begin{array}{c}\text { cała populacja w kontekście } \\
\text { całego życia }\end{array}$ \\
\hline Wykonawcy & $\begin{array}{l}\text { głównie resort zdrowia (działania } \\
\text { medyczne) }\end{array}$ & $\begin{array}{l}\text { uczestnictwo społeczeństwa, } \\
\text { działania wielosektorowe }\end{array}$ \\
\hline
\end{tabular}

Profilaktyka jest zatem wszelkimi „działaniami podejmowanymi w celu zapobieganiu pojawienia się i/lub rozwojowi niepożądanych zachowań, stanów lub zjawisk w danej społeczności. Istotą tych działań jest przeciwdziałanie zagrożeniom (w tym także chorobom, których wystąpienie lub nasilenie się jest w przyszłości prawdopodobne)" (Woynarowska, 2007: 127).

Wyróżnia się trzy poziomy/stopnie działań profilaktycznych

(1) Profilaktyka pierwszorzędowa (pierwotna) - obejmuje całą populację (lub przynajmniej większą jej część). Głównym celem podejmowanych działań jest uprzedzenie choroby lub zmniejszenie ryzyka jej rozwoju. W jej ramach stosuje się działania:

(a) swoiste - zapobieganie konkretnej chorobie, np. szczepienia ochronne;

(b) nieswoiste - zapobieganie wielu chorobom, np. aktywność fizyczna, prawidłowa dieta, wypoczynek. 


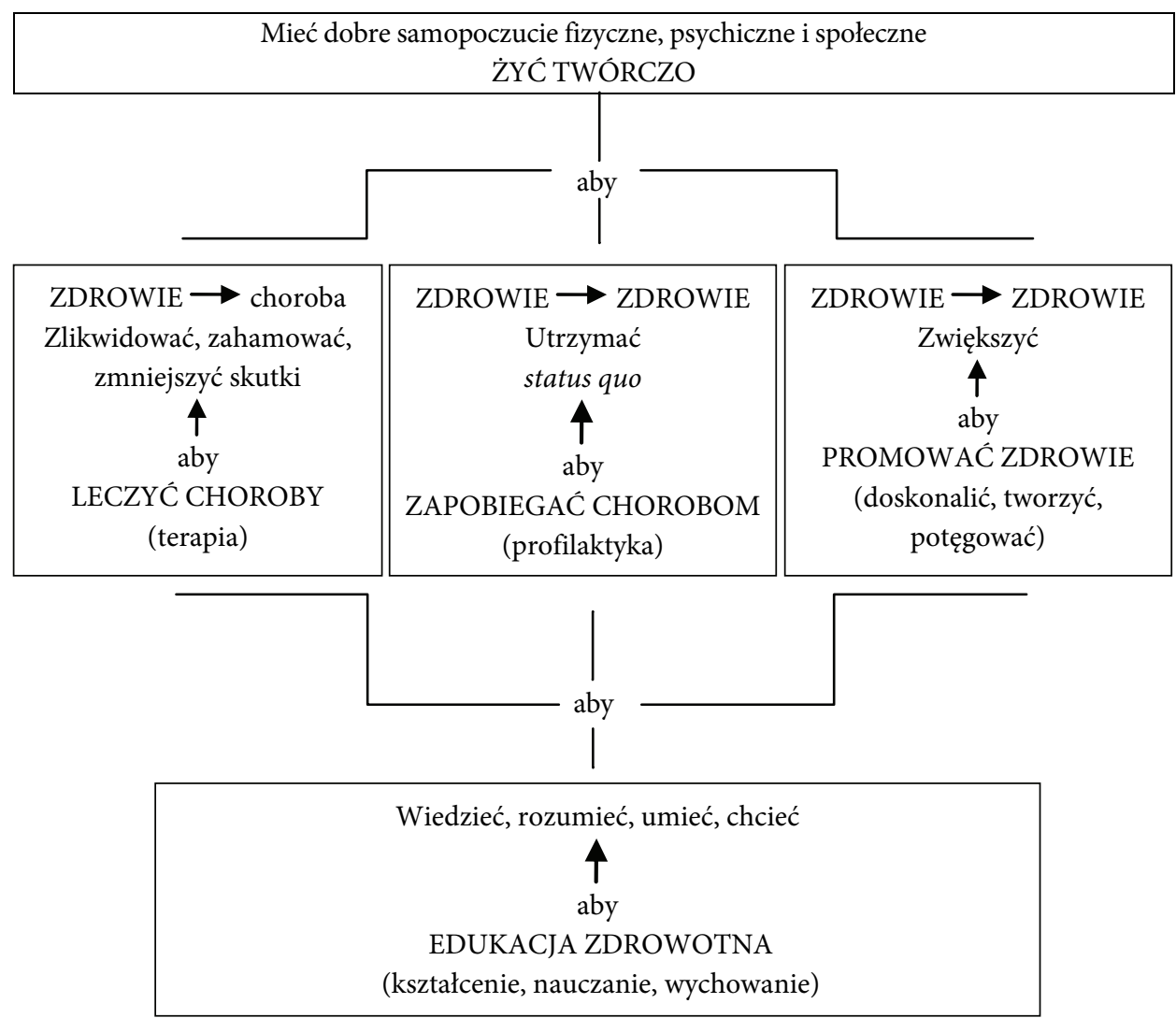

Rys. 1. Schemat powiązań między edukacją zdrowotną a terapią i profilaktyką oraz promocją zdrowia (źródło: Woynarowska, 2007: 126)

(2) Profilaktyka drugorzędowa (wtórna) - jest skierowana do określonej grupy populacji, w której występuje wyższy stopień ryzyka zaistnienia choroby. Celem jest wczesne wykrycie choroby i odpowiednio wczesne wdrożenie leczenia. Na tym poziomie stosuje się badania profilaktyczne, wśród których można wyróżnić trzy zasadnicze grupy:

(a) testy przesiewowe i profilaktyczne badania lekarskie dzieci i młodzieży;

(b) profilaktyczne badania lekarskie rożnych grup zawodowych;

(c) inne badania profilaktyczne u osób dorosłych $\mathrm{w}$ celu wykrycia najczęstszych chorób, np. pomiar ciśnienia tętniczego, stężenia cholesterolu w krwi. 
(3) Profilaktyka trzeciorzędowa - obejmuje działania rehabilitacyjne, rewalidacyjne, reedukacyjne. Odbiorcami są osoby przewlekle chore lub niepełnosprawne. $\mathrm{Na}$ tym poziomie działań profilaktycznych głównym celem jest zapobieganie dalszym negatywnym skutkom chorób lub niepełnosprawności poprzez:

(a) przywrócenie lub zastąpienie uszkodzonych funkcji;

(b) pomoc w radzeniu sobie $\mathrm{z}$ chorobą oraz w zaakceptowaniu swego stanu;

(c) pomoc w utrzymaniu dobrej kondycji psychicznej i fizycznej;

(d) zapobieganie izolacji społecznej, która może doprowadzić do wtórnego kalectwa (Woynarowska, 2007: 127-128).

Podobieństwa, różnice, a także zależności między powyższymi zagadnieniami zostały przedstawione na rys. 1 .

\section{Szkoła Promująca Zdrowie - przesłanki i założenia teoretyczne dla praktyki}

Poniżej zostaną omówione teoretyczne aspekty koncepcji Szkoły Promującej Zdrowie (SPZ) umożliwiające podjęcie praktyki w zakresie funkcjonowania szkoły o wspomnianym profilu. Barbara Woynarowska i Maria Sokołowska, korzystając z bogatego doświadczenia, wskazują pięć istotnych elementów niezbędnych w procesie tworzenia Szkoły Promującej Zdrowie. Są to: ludzie, koncepcja (idea), strategia, organizacja i model działania (Woynarowska, Sokołowska, 2000: 19). Zostaną one poniżej pokrótce scharakteryzowane. W pierwszej jednak kolejności zostanie przybliżona ogólna historia i idea Szkoły Promującej Zdrowie.

\section{Rodowód powstania koncepcji}

Historia powstania koncepcji Szkoły Promującej Zdrowie rozpoczyna swój bieg $\mathrm{w}$ latach 80. Była ona drugim z kolei przedsięwzięciem po Zdrowych Miastach podjętym w ramach ruchu promocji zdrowia. Jej założenia teoretyczne opracowano i rozpowszechniono w 1989 roku (Woynarowska, 1995: 16). Dwa lata później, tj. w roku 1991, Światowa Organizacja Zdrowia (Biuro Regionalne dla Europy) podjęła decyzję o wdrożeniu tego projektu, który początkowo nosił nazwę Zdrowa 
Szkoła, w życie. Jego realizację zaproponowano trzem krajom Europy Środkowo-Wschodniej - Polsce, Czechosłowacji oraz Węgrom (Woynarowska, 2000: 425).

W roku 1992 na mocy rozporządzeń trzech międzynarodowych organizacji: Światowej Organizacji Zdrowia (Biuro Regionalne dla Europy), Rady Europy i Komisji Europejskiej, podjęto decyzję o powołaniu Europejskiej Sieci Szkół Promujących Zdrowie (ESSPZ). Za jej działanie odpowiada Międzynarodowy Komitet Planowania, który mieści się w Kopenhadze (w siedzibie WHO). W roku jej powołania w jej szeregi przyjęto siedem państw: Polskę, Belgię, Danię, Czechosłowację, Grecję, Irlandię i Węgry. W roku 2005 należały do niej już 43 kraje. Podobne działania zaczęto wdrażać naiwnych kontynentach, np. w Ameryce Północnej czy Australii (Syrek, Borzucka-Sitkiewicz, 2009: 92).

W maju 1997 roku odbyła się I Konferencja Europejskiej Sieci Szkół Promujących Zdrowie. Miała ona miejsce w Grecji. Podczas jej trwania przyjęto rezolucję, która zatwierdzała tezę, iż „każde dziecko i młody człowiek ma prawo i powinien mieć możliwość uczenia się w Szkole Promującej Zdrowie" (Woynarowska, 2000: 425).

\section{Koncepcja Szkoły Promującej Zdrowie}

Idea Szkoły Promującej Zdrowie jest silnie powiązana z założeniami promocji zdrowia. Na chwile obecną nie istnieje ogólna definicja Szkoły Promującej Zdrowie. Według Światowej Organizacji Zdrowia, Szkołę Promującą Zdrowie wyróżniają trzy główne cechy:

(1) Obecność edukacji zdrowotnej w obowiązkowym programie nauczania.

(2) Etos zdrowia w szkole; problem ten związany jest ukrytym programem szkoły ${ }^{1}$, który uwzględnia: (a) środowisko fizyczne - czyste, bezpieczne i sprzyjające zdrowiu; (b) środowisko społeczne - właściwe relacje interpersonalne między jednostkami wchodzącymi w skład społeczności szkolnej; (c) politykę, a także organizację szkoły, wspierające edukację zdrowotną.

1 „Przez ukryty program szkoły rozumiemy wszystko to, czego uczy przebywanie w szkole, a nie nauczyciel" (Meigham, Barton, Walker, 1993: 71). 
(3) Współpraca z rodzicami i społecznością lokalną w celu wzmocnienia i utrwalenia wiadomości, których dziecko uczy się w szkole (Syrek, Borzucka-Sitkiewicz, 2009: 92).

W dokumentach Europejskiej Sieci Szkół Promujących Zdrowie z 1997 roku czytamy, iż głównym celem Szkoły Promującej Zdrowie jest zdrowy styl życia wszystkich członków społeczności szkolnej. By go zrealizować, szkoła powinna: (1) tworzyć wspierające, bezpieczne i przede wszystkim sprzyjające zdrowiu środowisko społeczne oraz fizyczne; (2) umożliwiać swymi decyzjami i działaniami wszystkim członkom społeczności szkolnej kontrolowanie i poprawianie stanu swojego zdrowia; (3) dokonywać zmian w stronę demokratyzacji i dialogu w zarządzaniu szkołą, relacjach międzyludzkich, metodach nauczania i uczenia się (Woynarowska, Sokołowska, 2000: 22).

Warto jednak nadmienić, iż mimo jasno określonych zasad tworzenia Szkół Promujących Zdrowie, każdy kraj określa własne cele i tworzy własny model Szkoły Promującej Zdrowie. Wynika to $\mathrm{z}$ faktu, iż tworzenie takiego modelu jest wynikiem dialogu i porozumienia pomiędzy jego twórcami. Ponadto, zależy on od uznawanych wartości oraz specyficznego kontekstu społecznego, w jakim jest tworzony, np. reformy systemu edukacji.

W Polsce przyjęto, iż projekt Szkoły Promującą Zdrowie będzie realizowany w oparciu o podejście siedliskowe, w którym społeczność szkolna:

(1) Podejmuje działania, by poprawić swoje zdrowie i samopoczucie poprzez zmianę zachowań prozdrowotnych oraz budowanie bezpiecznego i sprzyjającego zdrowiu środowiska fizycznego i społecznego.

(2) Nabywa umiejętności pełniejszego i zdrowszego życia dzięki edukacji zdrowotnej oraz osobistemu, społecznemu i zawodowemu rozwojowi.

(3) Zachęca społeczność lokalną (szczególnie rodziców) do podjęcia podobnych działań, czyniąc to poprzez dialog, partnerstwo i współdziałanie (Woynarowska, Sokołowska, 2001: 38).

\section{Klienci szkoły}

Ludzie to najistotniejsze ogniwo w tworzeniu koncepcji Szkoły Promującej Zdrowie. Bez ich udziału, idea ta nie miałaby podstaw i szans na realizację, gdyż jednym z kluczowych jej założeń jest wspomaganie rozwoju oraz umiejętności osobistych 
i społecznych jednostek (Syrek, Borzucka-Sitkiewicz, 2009: 100). Szkoła Promująca Zdrowie wykracza w swych działaniach poza mury szkoły, przez co promowana przez nią idea zdrowia znajduje szersze grono odbiorców, wśród których znajdują się: rodzice uczniów, przedstawiciele władz i społeczności lokalnej oraz osoby wspierające i nadzorujące pracę szkoły.

\section{Strategia szkoły}

Tworzenie Szkoły Promującej Zdrowie jest procesem często długotrwałym i wymagającym niejednokrotnie wykorzystywania nowych, niekonwencjonalnych rozwiązań, a także wielu strategii. Woynarowska i Sokołowska wskazują sześć podejśćl

strategii, które były wykorzystywane w praktyce Szkół Promujących Zdrowie. Są to: podejście siedliskowe, podejście „od ludzi do problemu”, podejście uczestniczące, strategia dokonywania zmian, demokratyzacja życia w szkole oraz strategia dialogu (Woynarowska, Sokołowska, 2001: 23-35). Zostały one bliżej przedstawione w części tekstu poświęconego zagadnieniu promocji zdrowia.

\section{Organizacja i proces tworzenia szkoły}

Jak już zostało wspomniane powyżej, proces tworzenia Szkoły Promującej Zdrowie jest długotrwały i wymaga zaangażowania wielu ludzi oraz podjęcia działań na różnych poziomach organizacji. Wyróżnia się cztery poziomy: szkolny, wojewódzki, krajowy i międzynarodowy. Cechą wyróżniającą organizację ruchu Szkoły Promującej Zdrowie jest budowanie sieci na wspomnianych poziomach, co tworzy swoisty system wsparcia dla grup społecznych oraz jednostek i umożliwia wymianę informacji i doświadczeń oraz podejmowanie wspólnych działań.

Sieć jest strukturą organizacji, w której nie ma określonej hierarchii. Obowiązują w niej tymczasowe ustalenia dotyczące obowiązków, uprawnień i odpowiedzialności, specjalizacja wynika z zainteresowań i fachowości, natomiast procedury są w minimalnym stopniu sformalizowane (Syrek, Borzucka-Sitkiewicz, 2009: 100).

Poniżej przedstawiony jest rysunek ukazujący relacje pomiędzy poszczególnymi poziomami organizacji. 


\section{Poziom szkolny}

1. Szkolny koordynator ds. promocji zdrowia - jest główną osobą odpowiadającą za realizację projektu. Do jego zadań należy: pozyskiwanie członków do projektu wśród społeczności szkolnej i społeczności lokalnej, inicjowanie i koordynowanie działań z zakresu promocji zdrowia, kierowanie pracą szkolnego zespołu promocji zdrowia, współudział w szerzeniu wiedzy z zakresu edukacji zdrowotnej i promocji zdrowia wśród pracowników szkoły, współpracowanie z zespołami wspierającymi działania szkoły (zespoły terenowe, wojewódzkie), rozwijanie własnych umiejętności z zakresu promocji zdrowia.

Warto również w tym miejscu przytoczyć słowa Lesława Kulmatyckiego, który pisze, iż: „koordynator ds. promocji zdrowia w szkole powinien być świadomy tego, że dokonywanie zmian jest swojego rodzaju wyzwaniem. Wyzwaniem w pierwszej kolejności skierowanym do samego siebie, następnie inspirowaniem tych zmian w innych, aby sami stawali się autorami tych zmian u siebie" (Kulmatycki, 1999: 7-13).

2. Szkolny zespół promocji zdrowia - w jego skład wchodzą przedstawiciele wszystkich grup społeczności szkolnej, a także rodzice i osoby z samorządu lokalnego. Zespół blisko współpracuje z koordynatorem. Każdy zespół ustala samodzielnie swoje reguły, zadania i organizacje swojej pracy.

\section{Poziom wojewódzki}

1. Wojewódzki koordynator Szkół Promujących Zdrowie - jest powoływany przez kuratora oświaty w porozumieniu z instytucjami i placówkami wchodzącymi w skład wojewódzkiego zespołu wspierającego Szkoły Promujące Zdrowie.

2. Wojewódzki zespół wspierający Szkoły Promujące Zdrowie - w jego skład wchodzą przedstawiciele resortu zdrowia i edukacji, a także inne resory i organizacje społeczne zarówno rządowe, jak i pozarządowe, pracujące na rzecz Szkół Promujących Zdrowie na danym terenie. Zespół działa na mocy porozumienia między kierownikami wspomnianych resortów i organizacji. Współpracuje z krajowym koordynatorem i zespołem wspierającym.

\section{Poziom krajowy}

1. Krajowy koordynator ds. projektu Szkoła Promująca Zdrowie - równocześnie pełni funkcję narodowego koordynatora w Europejskiej Sieci Szkół Promujących Zdrowie.

2. Zespół wspierający pracę szkół.

3. Rada programowa - w skład której wchodzą przedstawiciele różnych dyscyplin naukowych.

\section{Poziom międzynarodowy}

1. Międzynarodowy Komitet Planowania - został powołany przez Światowa Organizację Zdrowia, Radę Europy i Komisję Europejską.

Rys. 2. Szkoła Promująca Zdrowie na poszczególnych poziomach organizacji społecznej (źródło: opracowanie własne na podstawie: Woynarowska, Sokołowska, 2000: 36-47; Syrek, Borzucka-Sitkiewicz, 2009: 101-103). 


\section{Model (technologia) tworzenia Szkoły Promującej Zdrowie}

W Polsce tworzy się Szkoły Promujące Zdrowie w oparciu o strategię rozwiązywania problemów, którą zweryfikowano w czasie trwania projektu w latach 1992-1995. Model ten obejmuje pięć etapów. Ilustruje to tabela nr 2.

Tabela 2. Etapy tworzenia Szkoły Promującej Zdrowie (źródło: Woynarowska, Sokołowska, 2006: 32)

\section{Przygotowanie}

1. Inicjacja - narodzenie się pomysłu i chęci tworzenia SPZ w społeczności szkolnej.

2. Propagowanie idei $S P Z$ w społeczności szkolnej, wśród rodziców i społeczności lokalnej.

3. Pozyskiwanie uczestników i sojuszników. Powołanie szkolnego koordynatora i zespołu promocji zdrowia.

4. Podjęcie wzajemnych zobowiązań przez osoby przystępujące do działania.

\section{Diagnoza stanu wyjściowego}

1. Zebranie danych dotyczących aktualnych problemów, ludzi, warunków funkcjonowania szkoły itd.

2. Analiza tych danych.

3. Ustalenie listy problemów wymagających rozwiązania.

\section{Budowanie planu działań i ich ewaluacja}

1. Wybór problemu/ów priorytetowego/ych.

2. Określenie przyczyn tych problemów i sposobów usunięcia tych przyczyn.

3. Ustalenie celów.

4. Zbudowanie planu działań dla osiągnięcia celów.

\section{Działania}

1. Realizacja planu, monitorowanie działań (ewaluacja procesu) oraz dokonywanie niezbędnych korekt dla osiągnięcia celu.

\section{Ewaluacja wyników działań}

1. Ewaluacja końcowa - sprawdzenie, czy osiągnięto cel.

\section{Zakończenie}

Najważniejszym elementem odróżniającym koncepcję SPZ od innych dotychczasowych działań podejmowanych w ramach ruch na rzecz zdrowia jest to, iż wykracza ona swym programem poza obręb szkoły, tj. nawiązuje bliską współpracę $\mathrm{z}$ rodzicami oraz społecznością lokalną w celu rozwiązywania problemów zdrowotnych oraz ich zapobieganiu. 
Koncepcja SPZ oraz zasady jej tworzenia zostały klarownie opracowane, wyznaczając kierunek zmian funkcjonowania szkół. Mimo szczegółowych wytycznych, pozostawiono w tym modelu przestrzeń na interpretację celów i zdań stawianych w ramach promocji zdrowia, co sprawia, iż w każdym kraju, a w nim w każdej szkole, istnieje możliwość tworzenia własnej wizji SPZ i zmierzania do niej. Taki stan rzeczy wynika również z faktu, iż proponowany model jest wynikiem dialogu, współpracy oraz porozumienia pomiędzy jego twórcami. Ponadto, zależy on od uznawanych wartości i specyficznego kontekstu społecznego, w jakim jest tworzony, np. reforma systemu edukacji, zmiana systemu politycznego itp.

\section{Literatura}

Karski J. (2007). Praktyka i teoria promocji zdrowia. Warszawa.

Kasperek E. (1999). Zachowania prozdrowotne nauczycieli. Poznań.

Kulmatycki L. (1999). Co to jest szkoła promująca zdrowie. „Lider” nr 12, s. 7-13.

Majewicz P. (2011). Edukacja zdrowotna jako podstawowa forma promocji zdrowia wśród dzieci i młodzieży. [W:] Psychologia zdrowia dzieci i młodzieży. Perspektywa kliniczna. Red. W. Pilecka. Kraków, s. 135-145.

Majewicz P. (2011). Promocja zdrowia i edukacja zdrowotna - przedmiot, cele, zadania. [W]: Psychologia zdrowia dzieci i młodzieży. Perspektywa kliniczna. Red. W. Pilecka. Kraków, s. 121-135.

Parsons T. (1969). Struktura społeczna a osobowość. Warszawa.

Syrek E., Borzucka-Sitkiewicz K. (2009). Edukacja zdrowotna. Warszawa.

Woynarowska B. (1995). Edukacja zdrowotna w szkole. Warszawa.

Woynarowska B. (2000). Zdrowie i szkoła. Warszawa.

Woynarowska B. (2007). Edukacja zdrowotna. Warszawa.

Woynarowska B., Sokołowska M. (2000). Szkoła promująca zdrowie. Doświadczenia dziesięciu lat. Warszawa.

Woynarowska B., Sokołowska M. (2001). Ścieżka Edukacyjna - edukacja prozdrowotna i promocja zdrowia $w$ szkole. Warszawa.

Woynarowska B., Sokołowska M. (2006). Edukacja zdrowotna i promocja zdrowia w szkole. Warszawa.

\section{Health Promoting Schools. Theoretical Indications and Assumption for Practical Activities}

\section{Summary}

The purpose of this article is to bring the concept, history and organization of schools to promote health. The author in his considerations indicates how much important for the practical dimension of the project rationale and theoretical assumptions. 
The idea of promoting school health is strongly associated with the assumptions of health promotion. At the moment there is no general definition of health promoting school. According to the World Health Organization (WHO) to promote school health are distinguished by three main features:

- the presence of health of education in the compulsory curriculum,

- school health ethos, this problem is related to the hidden school program, which takes into account: (1) physical environment (clean, safe and conducive to health, (2) social environment (appropriate interpersonal relationships between entities forming part of the school community, (3) policy and school organization in support of health education,

- cooperation with parents and the local community in order to strengthen and reinforce the messages, which your child learns in school.

In the documents of European Network of Health Promoting Schools in 1997, it is said that the main objective of Promoting School Health is a healthy lifestyle for all members of the school community to achieve: (1) the school should create a secure and above all supportive social environment for health and physical development, (2) make decisions and actions of all members of the school community leading to control and improve the condition of your health, (3) make changes toward democratization and dialogue in the management of the school, relationship, methods of teaching and learning.

However, it is noted that in spite of the clear definition of health promoting schools, each country determines its own objectives and creates its own model to promotes school health, this is due to the fact that the creation of such model is the result of dialogue and agreement between its creators. In addition, it depends on the considered values and the specific social contest in which it is created, for example the reform of the education system. In Poland it is assumed that health promotion school project will be implemented on the basis of habitat.

The process of creating health promoting schools is long and requires the involvement of many people and is taking actions at different levels of the organization. There are four levels: school, district, national and international. The distinguishing feature of traffic organization promoting school health is to build on these levels, which creates a kind of support system for groups and individuals and allows the exchange of information or experience and to take joint action.

The network is a structure of the organization, which does not have the specified hierarchy, in its provisional findings concerning the duties, powers and responsibilities and the specialization according to interests and expertise. Procedures are minimally formalized.

The most important distinctive feature the concept of health promoting schools from other existing activities undertaken under the movement for health is that it extends its program outside school - establishes close cooperation with parents and the local community in order to solve health problems and their prevention.

The concept of promoting school health and the principles of its creation have been clearly drawn up, specifying the direction of changes in the functioning of schools. Although specific guidelines were left in this model space for interoperation purposes and sentences placed on the framework for health promotion, which means that in every country and in every school has ability to create their own vision of promoting school health and tend to it. 